\title{
PENGARUH PELATIHAN TERHADAP KINERJA KARYAWAN PADA LEMBAGA PERKREDITAN DESA (LPD) KABUPATEN BULELENG
}

\author{
Ni Wayan Eka Sri Anggereni \\ Jurusan Pendidikan Ekonomi \\ Universitas Pendidikan Ganesha \\ Singaraja, Indonesia \\ e-mail: sri.eka30@yahoo.com
}

\begin{abstract}
Abstrak
Penelitian ini bertujuan untuk mengetahui pengaruh pelatihan terhadap kinerja karyawan dan berapa besar pengaruh pelatihan terhadap kinerja karyawan pada Lembaga Perkreditan Desa Kabupaten Buleleng. Penelitian ini merupakan dalam jenis penelitian deskriptif kuantitatif. Data dikumpulkan dengan metode kuisioner, yang selanjutnya dianalisis menggunakan analisis regresi sederhana menggunakan IBM SPSS 24.0 for Windows. Hasil penelitian menunjukkan bahwa pelatihan berpengaruh positif dan signifikan terhadap kinerja karyawan, yang ditunjukkan dengan koefisien regresi yang positif 0,898 dengan nilai $t_{\text {hitung }}=10,947>t_{\text {tabel }}=$ 2,009 dan nilai probabilitas uji t 0,000 yang lebih kecil dari $\alpha=0,05$. Besar pengaruh pelatihan terhadap kinerja karyawan pada Lembaga Perkreditan Desa Kabupaten Buleleng ditunjukkan dengan koefisien determinasi sebesar 0,706. Hal ini menunjukkan bahwa 70,6\% kinerja karyawan dipengaruhi oleh pelatihan.
\end{abstract}

Kata kunci: pelatihan, kinerja karyawan.

\begin{abstract}
This research was aimed to identify the effect of training of the employee performance and the influence of training to employee performance of Village Credit Institution Buleleng District. This research was quantitative descriptive research. The data collected by questionnaires methods, and then analyzed by multiple regression analysis using IBM SPSS 24.0 for Windows. The results showed that training had a positive and significant effect on the employee performance, as indicated by positive regression coefficient 0.898 with value of test $=10.947>$ table $=2.009$ and probability value of t test $0.000<\alpha=0.05$. The influence of training to employee performance of Village Credit Institution Buleleng District was shown by coefficient of determination equal to 0.706 . This shows that $70.6 \%$ employee performance influenced by training.
\end{abstract}

Keywords: training, work productivity.

\section{PENDAHULUAN}

Pemanfaatan ilmu pengetahuan dan teknologi oleh organisasi atau perusahaan yang melakukan kegiatan usaha baik yang menghasilkan suatu produk, maupun yang memberikan pelayanan jasa bertujuan untuk mendapat keuntungan yang optimal, memberikan kepuasan kepada konsumen dan mampu bersaing dengan perusahaan lain. Untuk mencapai sasaran dan tujuan yang di inginkan oleh perusahaan tersebut, maka setiap bagian usaha harus dilaksanakan oleh tenaga kerja yang terampil.

Tenaga kerja mempunyai peranan yang sangat penting dalam mencapai tujuan perusahaan. Menurut Firdaus 
(2007:2), “Tenaga kerja adalah penduduk dalam usia kerja yang siap melakukan pekerjaan, antara lain mereka yang sudah bekerja, mereka yang sedang mencari pekerjaan, mereka yang sekolah, dan mereka yang mengurus rumah tangga". Sehingga tenaga kerja sebagai salah satu unsur dalam satu perusahaan seperti halnya mesin, uang, material dan metode yang berfungsi sebagai penggerak jalanya roda perusahaan sehingga mempunyai peranan yang sangat penting dalam mencapai tujuan perusahaan. Peran tenaga kerja penting dalam satu perusahaan karena manusia mempunyaiimajinasi yang tinggi sehingga dapat menghasilkan produk atau jasa yang dapat memberikan kepuasan kepada konsumen. Walaupun saat ini tenaga kerja manusia telah banyak digantikan oleh peralatan mesin, tetapi tenaga manusia masih diperlukan, karena tanpa adanya manusia yang menjalankan peralatan tersebut maka teknologi yang paling canggih sekalipun akan menjadi sesuatu yang tidak berguna.

Berbagai usaha untuk meningkatkan keterampilan, pengetahuan karyawan para pemimpin perusahaan telah menyadari berhasil atau tidaknya tujuan perusahaan tergantung pada unsur karyawannya. Oleh karena itu dalam usaha untuk memperoleh dan meningkatkan prestasi kerja yang baik tidak hanya dilakukan melalui cara penarikan tenaga kerja yang kompeten tetapi juga didukung usaha yang lain, salah satunya melalui pelatihan tenaga kerja. Menurut Hasibuan (2012:23), "pelatihan adalah bagian dari pendidikan yang menyangkut proses belajar untuk memperoleh dan meningkatkan keterampilan di luar sistem pendidikan yang berlaku, dalam waktu yang relatif singkat dengan metode yang lebih mengutamakan pelatihan dari pada teori". Sehingga untuk mendapatkan hasil yang baik maka para tenaga kerja tersebut harus diberi pengetahuan dan keterampilan yang cukup. Berdasarkan penelitian awal yang di lakukan pada LPLPD bahwa prestasi kerja karyawan LPD Kabupaten Buleleng masih rendah, ini terlihat dari karyawan yang masih belum terampil menggunakan komputer dalam menyelesaikan tugas yang harus diselesaikan dan lebih banyak menggunakan sistem manual dalam menyelesaikannya, sehingga waktu yang di perlukan untuk menyelesaikan tugas yang di berikan akan semakin lama. Selain itu karyawan LPD tingkat kedisplinanya dan rasa tanggung jawabnya masih rendah, hal ini terlihat dari pegawai LPD yang tidak tepat waktu dalam menyelesaikan tugas yang di berikan pimpinannya sehingga target-target yang ingin di capai oleh LPD yang ada di Kabupaten Buleleng tidak terpenuhi.

Oleh karena itu, untuk mencapai efisiensi dan produktivitas seorang pemimpin harus dapat mengetahui dan melayani kebutuhan pegawainya. Besar kecilnya hasil yang diberikan oleh karyawan dapat terpenuhi apabila mereka diberikan kesempatan untuk mengembangkan kecakapan mereka sesuai dengan kemampuan sebagai karyawan sehingga dapat meningkatkan prestasi kerjanya. Oleh karena itu LPD yang ada di Kabupaten Buleleng melaksanakan pelatihan yang di bina oleh Bank BPD Bali Cabang Singaraja, BKS LPD, LPLPD Provinsi Bali dan Team Pembina LPD se-Kabupaten Buleleng dengan narasumbernya, yaitu Ketua BKS LPD Provensi Bali Drs. I Nyoman Cendikiawan, I Nyoman Arnaya, sekretaris LPLPD Provinsi Bali, Gede Seniara, Kepala LPLPD Kabupaten Buleleng yang dilaksanakan di hotel Bali Taman Singaraja.

Pelatihan memiliki peranan yang penting daam meningkatkan keterampilan dan keahlian karyawan. Menurut Simamora (2006:273) "Pelatihan (training) merupakan proses pembelajaran yang melibatkan perolehan keahlian, konsep, peraturan, atau sikap untuk meningkatkan kinerja karyawan. Menurut Pasal 1 Ayat 9 UndangUndang No. 13 Tahun 2003, pelatihan kerja adalah keseluruhan kegiatan untuk memberi, memperoleh, meningkatkan, serta mengembangkan kompetensi kerja, produktivitas, disiplin, sikap, dan etos kerja pada tingkat keterampilan dan keahlian tertentu sesuai dengan jenjang dan kualifikasi jabatan dan pekerjaan. Menurut Hasibuan (2012:23) "pelatihan adalah bagian dari pendidikan yang menyangkut proses belajar untuk memperoleh dan 
meningkatkan keterampilan di luar system pendidikan yang berlaku, dalam waktu yang relatif singkat dengan metode yang lebih mengutamakan pelatihan dari pada teori". Menurut Sikula yang dikutip oleh Mangkunegara (2003:50), pelatihan adalah suatu proses pendidikan jangka pendek yang mempergunakan prosedur sistematis dan terorganisir di mana pegawai mempelajari pengetahuan dan kemampuan teknis dalam tujuan terbatas. Dari penjelasan di atas, maka dapat disimpulkan bahwa pelatihan adalah sesuatu usaha yang di lakukan oleh perusahaan untuk meningkatkan keterampilan teknis pelaksanaan kerja karyawan, dalam waktu yang relatif singkat.

Kualitas pelatihan yang dilakukan suatu perusahaan dapat diukur dengan menggunakan indikator. Menurut Simamora (2006:170), indikator yang digunakan untuk mengukur pelatihan adalah sebagai berikut.

(1) Rekrutmen dan seleksi trainee dan trainer, adanya ketepatan rekrutmen peserta dan instruktur pelatihan yang dilakukan oleh pimpinan; (2) Materi pelatihan dengan tuntutan pekerjaan, adanya relevansi materi pelatihan yang diberikan oleh instruktur dengan pekerjaan; (3) Ketepatan metode pelatihan, adanya ketepatan metode pelatihan yang diterapkan oleh instruktur dalam melakukan pelatihan; (4) Proses dan pelaksanaan pelatihan, adanya ketepatan proses pelaksanaan pelatihan yang diterapkan di tempat pelatihan; (5) Evaluasi pelaksanaan pelatihan, adanya ketepatan evaluasi pelaksanaan pelatihan yang diterapkan di tempat pelatihan; (6) Penempatan trainee pada pekerjaannya setelah pelatihan, adanya kesesuaian penempatan karyawan oleh pimpinan dengan pelatihan yang pernah ikuti; (7) Kompensasi karyawan setelah pelatihan, adanya ketersediaan kompensasi finansial dan non finansial yang disiapkan bagi karyawan yang telah mengikuti pelatihan; (8) Dampak pelatihan terhadap kinerja karyawan, adanya kesesuaian pelatihan yang pernah diikuti dengan kinerja karyawan;

Kinerja berasal dari kata job performance yang berarti prestasi kerja atau prestasi sesungguhnya yang dicapai oleh seseorang. Pengertian kinerja (prestasi kerja) adalah hasil kerja secara kualitas dan kuantitas yang dicapai oleh seseorang pegawai dalam melaksanakan fungsinya sesuai dengan tanggung jawab yang diberikan kepadanya. Menurut llyas (2005:55), kinerja adalah penampilan, hasil karya personil baik kualitas maupun kuantitas penampilan individu maupun kelompok kerja personil, penampilan hasil karya tidak terbatas pada kepada personil yang memangku jabatan fungsional maupun strukturual tetapi juga kepada keseluruhan jajaran personil didalam organisasi. Senada dengan itu, Rivai (2005:309) menyatakan bahwa kinerja adalah perilaku nyata yang ditampilkan setiap orang sebagai prestasi kerja yang dihasilkan oleh karyawan sesuai dengan perannya dalam perusahaan. Dari penjelasan tersebut, dapat disimpulkan bahwa kinerja adalah hasil yang dicapai oleh seseorang dalam melaksanakan tugas atau tanggung jawab menurut ukuran dan standar yang berlaku pada masing masing organisasi.

Kinerja karyawan dipengaruhi oleh beberapa faktor. Menurut Nitisemito (2001:109), terdapat berbagai faktor kinerja karyawan, yaitu jumlah dan komposisi dari kompensasi yang diberikan, penempatan kerja yang tepat, pelatihan dan promosi, rasa aman di masa depan (dengan adanya pesangon dan sebagainya), hubungan dengan rekan kerja, dan hubungan dengan pemimpin. Sedana dengan itu, Mangkuprawira dan Hubeis (2007:160) menyatakan bahwa kinerja karyawan dipengaruhi oleh faktor intrinsik dan ektrinsik karyawan sebagai berikut. (1) Faktor intrinsik yang mempengaruhi kinerja pegawai terdiri dari pendidikan, pengalaman, motivasi, kesehatan, usia, keterampilan, emosi, dan spiritual; (2) Faktor ekstrinsik yang mempengaruhi kinerja pegawai terdiri dari lingkungan fisik dan non fisik, kepemimpinan, komunikasi vertikal dan horizontal, kompensasi, kontrol berupa penyeliaan, fasilitas, pelatihan, beban kerja, prosedur kerja, sistem hukuman dan sebagainya;

Kinerja juga dipengaruhi oleh faktor kemampuan (ability) dan faktor motivasi. 
Mangkunegara (2005:13), ada beberapa faktor yang mempengaruhi kinerja. kemampuan reality. Kemampuan potensi adalah suatu kemampuan, kesanggupan, kekuatan ataupun daya yang mempunyai kemungkinan untuk bisa dikembangkan lagi menjadi bentuk yang lebih besar. Sedangkan, kemampuan reality (knowledge, skill) adalah pimpinan dan karyawan yang memiliki IQ di atas rata-rata (IQ 110 - 120) apalagi dengan pendidikan yang memadai untuk jabatannya dan terampil dalam pekerjaan sehari-hari, maka lebih mudah mencapai kinerja maksimal. Kedua, faktor motivasi (motivation), yang diartikan sebagai suatu sikap pimpinan dan karyawan terhadap situasi kerja di lingkungan organisasinya. Mereka yang bersikap positif terhadap situasi kerjanyan akan menunjukkan motivasi kerja yang tinggi dan sebaliknya jika mereka bersikap negatif terhadap situasi kerjanya akan menunjukkan motivasi kerja yang rendah.

Tingkat kinerja karyawan dapat diukur dengan menggunakan indikator. Menurut Wirawan (2009:7), indikator yang digunakan untuk mengukur kinerja adalah sebagai berikut. (1) Kuantitas hasil kerja, yaitu kinerja dapat diukur dari target kerja yang telah berhasil dicapai dan volume pekerjaan yang dilakukan sesuai dengan harapan atasan; (2) Kualitas hasil kerja, yaitu kinerja dapat diukur dari kesesuaian hasil kerja sesuai dengan standar kerja, penyelesaian pekerjaan tepat waktu, dan hasil pekerjaan akurat; (3) Efisiensi dalam melaksanakan tugas, yaitu kinerja dapat diukur dari efisiensi dalam melaksanakan tugas-tugas perusahaan yang terwujud dengan ketepatan waktu dalam menyelesaikan pekerjaan; (4) Disiplin kerja, yaitu kinerja dapat diukur dari kehadiran sudah sesuai dengan jam kerja yang ditetapkan oleh perusahaan dan jam masuk kerja dan pulang kerja sudah sesuai dengan jam kerja yang ditetapkan oleh perusahaan; (5) Inisiatif, yaitu kinerja dapat diukur dari kesungguhan karyawan bekerja untuk memikul tanggung jawab yang lebih besar dan kesadaran karyawan untuk memajukan perusahaan; (6) Ketelitian, yaitu kinerja dapat diukur dari ketelitian bekerja dalam melakukan pelayanan dan
Pertama, faktor kemampuan (ability), yang terdiri dari kemampuan potensi dan keakuratan bekerja dalam mencatat transaksi yang ada di perusahaan; (7) Kepemimpinan, yaitu kinerja dapat diukur dari ketegasan dalam mengambil keputusan dalam bekerja dan menjaga kekompakan dengan rekan kerja; (8) Kejujuran, yaitu kinerja dapat diukur dari kejujuran dalam bekerja dan tidak melakukan kecurangan dalam melaksanakan pekerjaan; (9) Kreativitas, yaitu kinerja dapat diukur dari karyawan mengembangkan gagasan baru dalam pekerjaannya dan mengikuti perubahan dan belajar secara terus-menerus dalam pekerjaannya;

Secara teoritis ada beberapa pandangan mengenai hubungan pelaksanaan program pelatihan dengan kinerja karyawan, antara lain menurut Stoner (dalam Sutrisno, 2010:210) yang mengatakan bahwa peningkatan kinerja bukan pada pemuktahiran peralatan, akan tetapi pada pengembangan karyawan paling utama. Oleh karena itu, pelatihan terhadap karyawan dapat dijadikan sebagai salah satu cara bagi perusahaan untuk mengasah keahlian tenaga kerja yang dimiliki dalam meningkatkan kinerja sesuai dengan standar yang ditetapkan perusahaan. Menurut Kussriyanto (2003:10), pelatihan dapat menambah pengalaman dan meningkatkan keterampilan kerja mempunyai dampak paling langsung terhadap kinerja. Pendapat lain datang dari Hasibuan (2006:77) menyatakan bahwa pelaksanaan program pelatihan membentuk dan meningkatkan kemampuan dan pengetahuan karyawan, sehingga diharapkan jika semakin sering program pelatihan dilaksanakan maka semakin tinggi pula tingkat kinerjanya. Hal ini didukung oleh kajian empirik dari Yusnita (2014), yang meneliti tentang "pengaruh Pelatihan Terhadap Kinerja Karyawan Pada PT PDAM Tirta Pakuan Kota Bogor". Penelitiannya bertujuan untuk mengetahui pelaksanaan pelatihan yang diterapkan dan untuk mengetahui tingkat pelayanan karyawan, serta untuk mengetahui pengaruh pelatihan terhadap kinerja karyawan pada PT PDAM Tirta Pakuan 
Kota Bogor. Jenis penelitian ini adalah jenis verifikatif dengan metode penelitian explanatory survey. Pengumpulan data dilakukan dengan menggunakan kuesioner. Teknik analisis data yang digunakan adalah analisis regresi linier sederhana. Hasil penelitian menunjukkan bahwa analisis koefesien korelasi diperoleh $r=0,714$. Angka tersebut menunjukan hubungan antara pelatihan dengan kinerja karyawan memiliki tingkat hubungan yang kuat. Berdasarkan dari analisis koefesiensi determinasi 50,9\%. Hal ini menunjukan bahwa pelatihan menentukan turun naiknya kinerja karyawan PT PDAM Tirta Pakuan Kota Bogor $20,90 \%$ dan selebihnya $74,1 \%$ dipengaruhi faktor lain. Berdasarkan dari analisis uji hipotesis koefesiensi korelasi di peroleh $t$ hitung $(8,347)>t$ tabel $(1,661)$ sehingga $\mathrm{H}_{0}$ ditolak. Jadi, dapat disimpulkan bahwa pelatihan mempunyai hubungan yang signifikan dan positif terhadap kinerja karyawan.

Penelitian lainnya dilakukan oleh Sugiarti (2016), yang meneliti tentang "Pengaruh Pelatihan Kerja Terhadap Kinerja Karyawan Pada PT Padma Ardya Aktuaria Jakarta". Penelitiannya bertujuan untuk untuk menjelaskan pengaruh pelatihan kerja terhadap kinerja karyawan pada perusahaan PT Padma Ardya Aktuaria Jakarta. Penelitian ini menggunakan bentuk penelitian survey dengan rumusan hipotesis asosiatif. Pengumpulan data dilakukan dengan menggunakan kuesioner. Teknik analisis data yang digunakan adalah analisis regresi linier sederhana. Hasil penelitian menunjukkan bahwa pelatihan memiliki hubungan dengan tingkat sedang dan memiliki pengaruh yang signifikan dan positif terhadap kinerja karyawan. Dilihat dari beberapa hasil analisis, yaitu analisis koefisien korelasi sebesar 0,507, dilihat dari hasil analisis uji $\mathrm{t}$ di peroleh nilai t hitung $(2,878)>t$ tabel $(1,711)$ dengan nilai signifikasi sebesar 0,008 $<0,05$, maka $\mathrm{Ha}$ diterima dan Ho ditolak dan hasil uji regresi linear sederhana yang menunjukan nilai koefisien beta positif. Besarnya pengaruh pelatihan terhadap kinerja karyawan yaitu $25,7 \%$ dan sisanya sebesar $74,3 \%$ dipengaruhi oleh variabel lain. Meskipun pelatihan tenaga kerja memerlukan biaya yang tidak sedikit, tetapi pelatihan harus tetap dilaksanakan karena pelatihan tersebut mempunyai manfaat yang sangat besar, baik bagi perusahaan maupun bagi karyawan perusahaan. Manfaat bagi perusahaan antara lain adalah perusahaan mempunyai tenaga kerja yang siap melaksanakan pekerjanya sehingga dengan adanya tenaga kerja yang demikian perusahaan dapat mencapai tujuannya dengan lebih mudah. Manfaat bagi karyawan itu sendiri adalah mereka dapat mengembangkan sikap, prilaku, keterampilan, dan pengetahuan tentang pekerjanya. Hal ini akan meningkatkan prestasi kerja para karyawan yang bersangkutan, sehingga dapat lebih menunjang tercapainya tujuan perusahaan secara efesien dan efektif.

Berdasarkan uraian di atas, maka penulis tertarik melakukan penelitian yang bertujuan untuk, (1) Untuk mengetahui pengaruh pelatihan terhadap kinerja karyawan pada LPD Kabupaten Buleleng. (2) Untuk mengetahui seberapa besar pengaruh pelatihan terhadap kinerja karyawan pada LPD Kabupaten Buleleng.

\section{METODE}

Rancangan penelitian yang digunakan dalam penelitian ini adalah penelitian kausalitas. Menurut (Zuriah, 2006:57) penelitian kausalitas bertujuan untuk menemukan hubungan sebab-akibat berdasarkan pengamatan terhadap akibat yang terjadi dan mencari faktor yang menjadi penyebab melalui data yang dikumpulkan. Adapun variabel-variabel yang digunakan dalam penelitian ini adalah pelatihan $(\mathrm{X})$ dan kinerja karyawan (Y). Hasil yang diharapkan dapat menjelaskan mengenai pengaruh pelatihan terhadap kinerja karyawan pada Lembaga Perkreditan Desa (LPD) Kabupaten Buleleng.

Penelitian ini dilakukan pada (LPD) Kabupaten Buleleng, Provinsi Bali. Subjek penelitian ini adalah karyawan (LPD) Kabupaten Buleleng, sedangkan objek penelitian ini adalah variabel pelatihan dan kinerja karyawan. Jenis data penelitian ini adalah data kuantitatif, yaitu data berupa 
angka-angka yang diperoleh dari jawaban responden mengenai kuesioner pelatihan dan data kinerja karyawan (LPD) Kabupaten Buleleng. Data primer pada penelitian ini adalah data yang diperoleh langsung dari subjek yang diteliti. Data primer penelitian ini berupa kuesioner pelatihan dan kinerja karyawan (LPD) Kabupaten Buleleng. Data sekunder pada penelitian ini adalah data yang diperoleh secara tidak langsung dari subjek yang diteliti. Data sekunder penelitian ini berupa data dokumen nama karyawan LPD di Kabupaten Buleleng.

Adapun metode pengumpulan data yang digunakan dalam penelitian ini adalah metode dokumentasi dipergunakan untuk mengumpulkan atau memperoleh data berupa nama karyawan dan jumlah karyawan Lembaga Perkreditan Desa (LPD) di Kabupaten Buleleng. Metode kuesioner digunakan untuk mendapatkan data tentang pelatihan dan kinerja karyawan.

Data yang telah dikumpulkan digunakan sistem skor, dimana jawaban pertanyaan diberi skor dengan menggunakan skala likert. Menurut (Sugiyono, 2013:132) skala likert merupakan skala yang digunakan untuk mengukur, sikap, pendapat, dan persepsi seseorang atau sekelompok orang tentang fenomena sosial. Setiap pernyataan disediakan 5 (lima) alternatif jawaban. Untuk kuesioner pelatihan memiliki pilihan jawaban, yaitu sangat kurang baik (SKB), kurang baik $(K B)$, cukup baik $(C B)$, baik $(B)$, sangat baik (SB). Untuk kuesioner kinerja karyawan memiliki pilihan jawaban, yaitu tidak pernah (TP), jarang (JR), kadangkadang (KD), sering (S), selalu (SL). Skor tersebut agar dapat diolah menggunakan analisis regresi linier sederhana, dimana data ordinal (skor kuesioner) tersebut terlebih dahulu harus ditransformasikan menjadi data interval dengan bantuan MSI (Method of Successive Interval). Kuesioner sebagai instrumen pengumpulan data sebelum digunakan untuk mengumpulkan data di lapangan terlebih dahulu harus diuji tingkat validitas dan reliabilitasnya. Untuk menguji tingkat validitas dan reliabilitas instrumen penelitian akan diujikan kepada
30 responden.

Validitas adalah untuk melihat kecermatan alat ukur, yaitu mengukur apa yang akan diukur. Dalam penelitian ini, suatu kuesioner dinyatakan valid, jika pertanyaan maupun pernyataan pada kuesioner mampu untuk mengungkapkan sesuatu yang akan diukur oleh kuesioner tersebut. Pengujian validitas dalam penelitian ini dilakukan dengan menggunakan Person Correlation yang terdapat dalam program IBM SPSS 24.0 for Windows. Suatu pertanyaan dikatakan valid jika tingkat signifikasinya di bawah 0,05 (Ghozali, 2011:53).

Reliabilitas berkaitan dengan keterandalan suatu indikator. Informasi yang ada pada indikator ini tidak berubahubah, atau bisa disebut dengan kosisten. Uji reabilitas dilakukan untuk menguji apakah jawaban dari responden konsisiten. Suatu angket dikatakan reliabel jika jawaban seseorang terhadap pertanyaan adalah konsisten atau stabil dari waktu ke waktu. Menurut (Ghozali,2011:48) Pengujian realibilitas dalam penelitian ini dilakukan dengan menggunakan Alpha Cronbach yang terdapat dalam program SPSS 24.0 for Windows. Suatu instrumen dikatakan reliabel jika memiliki nilai Alpha Cronbach > 0,70.

Analisis data dilakukan untuk menguji hipotesis yang diajukan, yaitu untuk mengetahui ada tidaknya hubungan antara variabel bebas $(X)$ dengan variabel terikat $(Y)$, sedangkan teknik analisis data yang digunakan dalam penelitian ini andalah regresi linier sederhana. Regresi linier sederhana digunakan untuk mengetahui pengaruh antara satu variabel bebas terhadap variabel terikat (Dantes, 2012:35). Sebelum dilakukan pengujian analisis regresi linear sederhana, maka dilakukan pengujian prasyarat, yaitu uji asumsi klasik yang terdiri dari uji normalitas.

Pengujian hipotesis menggunakan uji t. Uji t dilakukan untuk melihat signifikan dari pengaruh independen secara individu terhadap variabel dependen. Pengujian ini dilakukan dengan membandingkan t hitung dengan $\mathrm{t}$ tabel. Adapun langkah-langkah pengujiannya, yaitu: (1) perumusan hipotesis, (2) menentukan tingkat signifikan 
(a) yaitu sebesar $5 \%$, (3) menentukan kriteria penerimaan atau penolakan $\mathrm{H}_{0}$ dengan melihat nilai signifikan. Jika signifikan $<5 \%$ maka $\mathrm{H}_{0}$ ditolak dan jika signifikan $>5 \%$ maka $\mathrm{H}_{0}$ diterima, dan (4) pengambilan keputusan. Analisis determinasi bertujuan untuk mengetahui atau menentukan seberapa besar pengaruh pelatihan terhadap kinerja karyawan Lembaga Perkreditan Desa (LPD) di Kabupaten Buleleng. Untuk menghitung koefisien determinasi $\left(R^{2}\right)$.

\section{HASIL DAN PEMBAHASAN \\ Hasil}

Pengaruh pelatihan terhadap kinerja karyawan pada Lembaga Perkreditan Desa (LPD) Kabupaten Buleleng dapat diketahui dengan menggunakan uji t. Perhitungan uji t menggunakan bantuan program IBM SPSS 24.0 for Windows dan pengujian hipotesis dilakukan pada taraf signifikansi 5\%. Hasil uji t dapat dilihat pada Tabel 1.

Tabel 1. Hasil Uji t

\begin{tabular}{|c|c|c|c|c|c|c|}
\hline \multirow{2}{*}{\multicolumn{2}{|c|}{ Model }} & \multicolumn{2}{|c|}{$\begin{array}{c}\text { Unstandardized } \\
\text { Coefficients }\end{array}$} & \multirow{2}{*}{$\begin{array}{c}\text { Standardized Coefficients } \\
\text { Beta }\end{array}$} & \multirow[t]{2}{*}{$t$} & \multirow[t]{2}{*}{ Sig. } \\
\hline & & B & Std. Error & & & \\
\hline \multirow[t]{2}{*}{1} & (Constant) & 14,647 & 2,806 & & 5,220 & 0,000 \\
\hline & Pelatihan & 0,898 & 0,082 & 0,840 & 10,947 & 0,000 \\
\hline
\end{tabular}

a. Dependent Variable: Kinerja Karyawan

Berdasarkan Tabel 1, diperoleh nilai $t_{\text {hitung }}=10,947$ dengan nilai $p$-value sebesar 0,000 . Nilai $t_{\text {hitung }}=10,947$ lebih besar dari $t_{\text {tabel }}=2,009$ dan $p$-value sebesar 0,000 lebih kecil dari $\alpha=0,05$, maka keputusannya $\mathrm{H}_{0}$ ditolak. Jadi, terdapat pengaruh yang positif dan signifikan antara pelatihan terhadap kinerja karyawan pada Lembaga Perkreditan Desa (LPD) Kabupaten Buleleng.

Berdasarkan hasil analisis regresi linier sederhana, dapat diketahui persamaan garis regresi untuk mengetahui hubungan pelatihan terhadap kinerja karyawan pada Lembaga Perkreditan Desa (LPD) Kabupaten Buleleng dengan menggunakan analisis koefisien beta.

Berdasarkan output IBM SPSS 24.0 for Windows analisis persamaan regresi pada Tabel 1, maka didapat hasil persamaan regresi sebagai berikut.

$$
\hat{\mathrm{Y}}=14,647+0,898 \hat{\mathrm{X}}
$$

Keterangan:

$\hat{Y}=$ kinerja karyawan

$\hat{\mathrm{X}}=$ pelatihan

Berdasarkan model persamaan
regresi yang terbentuk, dapat
diinterpretasikan hasil bahwa konstanta
sebesar 14,647 menunjukan jika variabel
pelatihan $(X)$ bernilai konstan atau nol,

maka variabel kinerja karyawan $(Y)$ memiliki nilai positif sebesar 14,647. Selanjutnya, variabel pelatihan $(X)$ memiliki koefisien positif sebesar 0,898 . Nilai koefisien regresi yang positif menunjukkan bahwa pelatihan (X) berpengaruh positif terhadap kinerja karyawan (Y). Hal ini menggambarkan bahwa peningkatan pelatihan $(\mathrm{X})$ sebesar satu satuan akan dapat meningkatkan kinerja karyawan $(Y)$ sebesar nilai koefisien beta masing-masing variabel bebas dikalikan dengan besar kenaikan yang terjadi. Misalnya, setiap terjadi kenaikan pelatihan $(X)$ sebesar 1 satuan, maka akan meningkatkan kinerja karyawan $(\mathrm{Y})$ sebesar 0,898 . Hal ini menunjukkan bahwa semakin sering dilakukan pelatihan, maka semakin tinggi kinerja karyawan pada Lembaga Perkreditan Desa (LPD) Kabupaten Buleleng, semakin jarang dilakukan pelatihan, maka semakin rendah kinerja karyawan pada Lembaga Perkreditan Desa (LPD) Kabupaten Buleleng.

Untuk mengetahui seberapa besar pengaruh pelatihan terhadap kinerja karyawan pada Lembaga Perkreditan Desa (LPD) Kabupaten Buleleng digunakan koefisien determinasi, yang ditunjukkan dengan nilai $R$ Square. Hasil analisis koefisien determinasi dapat disajikan pada Tabel 2. 
Tabel 2. Hasil Perhitungan Koefisien Determinasi

\begin{tabular}{ccccc}
\hline Model & $\mathrm{R}$ & $\mathrm{R}$ Square & Adjusted R Square & Std. Error of the Estimate \\
\hline 1 & 0,840 & 0,706 & 0,700 & 4,286036 \\
\hline
\end{tabular}

a. Predictors: (Constant), $\mathrm{X}$

Berdasarkan Tabel 2, diketahui bahwa hasil perhitungan koefisien determinasi sebesar 0,706. Hal ini menunjukkan bahwa $70,6 \%$ variabel kinerja karyawan pada Lembaga Perkreditan Desa (LPD) Kabupaten Buleleng dipengaruhi oleh variabel pelatihan, sedangkan $29,4 \%$ dipengaruhi oleh faktor lain yang tidak termasuk dalam penelitian ini.

\section{Pembahasan}

Hasil penelitian menunjukkan bahwa terdapat pengaruh yang positif dan siginifikan antara pelatihan dengan kinerja karyawan. Persamaan regresi punya arah koefisien positif sebesar 0,898. Pengaruh positif menunjukkan bahwa hubungan pelatihan dan kinerja karyawan adalah searah. Jika pelatihan semakin sering, maka kinerja karyawan juga semakin tinggi. Terdapat pengaruh yang signifikan pelatihan terhadap kinerja karyawan, yang ditunjukkan dengan nilai probabilitas uji t untuk pelatihan adalah 0,000 lebih kecil dari 0,05 .

Berdasarkan hasil analisis regresi linier sederhana, maka dapat diambil suatu kesimpulan bahwa terdapat pelatihan berpengaruh positif dan signifikan terhadap kinerja karyawan. Hasil penelitian ini didukung oleh hasil penelitian terdahulu yang dilakukan oleh Yusnita (2014), yang meneliti tentang "Pengaruh Pelatihan Terhadap Kinerja Karyawan Pada PT PDAM Tirta Pakuan Kota Bogor". Penelitiannya bertujuan untuk mengetahui pelaksanaan pelatihan yang diterapkan dan untuk mengetahui tingkat pelayanan karyawan, serta untuk mengetahui pengaruh pelatihan terhadap kinerja karyawan pada PT PDAM Tirta Pakuan Kota Bogor. Jenis penelitian ini adalah jenis verifikatif dengan metode penelitian explanatory survey. Pengumpulan data dilakukan dengan menggunakan kuesioner. Teknik analisis data yang digunakan adalah analisis regresi linier sederhana. Hasil penelitian menunjukkan bahwa analisis koefesien korelasi diperoleh $r=0,714$.
Angka tersebut menunjukan hubungan antara pelatihan dengan kinerja karyawan memiliki tingkat hubungan yang kuat. Berdasarkan dari analisis koefesiensi determinasi $50,9 \%$. Hal ini menunjukan bahwa pelatihan menentukan turun naiknya kinerja karyawan PT PDAM Tirta Pakuan Kota Bogor $20,90 \%$ dan selebihnya $74,1 \%$ dipengaruhi faktor lain. Berdasarkan dari analisis uji hipotesis koefesiensi korelasi di peroleh $\mathrm{t}$ hitung $(8,347)>\mathrm{t}$ tabel $(1,661)$ sehingga $\mathrm{H}_{0}$ ditolak. Jadi, dapat disimpulkan bahwa pelatihan mempunyai hubungan yang signifikan dan positif terhadap kinerja karyawan.

Penelitian lain yang mendukung hasil penelitian ini dilakukan oleh Sugiarti (2016), yang meneliti tentang "Pengaruh Pelatihan Kerja Terhadap Kinerja Karyawan Pada PT Padma Ardya Aktuaria Jakarta". Penelitiannya bertujuan untuk untuk menjelaskan pengaruh pelatihan kerja terhadap kinerja karyawan pada perusahaan PT Padma Ardya Aktuaria Jakarta. Penelitian ini menggunakan bentuk penelitian survey dengan rumusan hipotesis asosiatif. Pengumpulan data dilakukan dengan menggunakan kuesioner. Teknik analisis data yang digunakan adalah analisis regresi linier sederhana. Hasil penelitian menunjukkan bahwa pelatihan memiliki hubungan dengan tingkat sedang dan memiliki pengaruh yang signifikan dan positif terhadap kinerja karyawan. Dilihat dari beberapa hasil analisis, yaitu analisis koefisien korelasi sebesar 0,507, dilihat dari hasil analisis uji $\mathrm{t}$ di peroleh nilai $\mathrm{t}$ hitung $(2,878)>t$ tabel $(1,711)$ dengan nilai signifikasi sebesar $0,008<0,05$, maka $\mathrm{H}_{0}$ ditolak dan hasil uji regresi linear sederhana yang menunjukan nilai koefisien beta positif. Besarnya pengaruh pelatihan terhadap kinerja karyawan yaitu $25,7 \%$ dan sisanya sebesar $74,3 \%$ dipengaruhi oleh variabel lain.

Hasil penelitian ini didukung teori yang dikemukan oleh Mangkuprawira dan Hubeis (2007:160) menyatakan bahwa kinerja 
karyawan dipengaruhi oleh faktor ektrinsik karyawan, salah satunya adalah pelatihan. Menurut Kussriyanto (2003:10), pelatihan dapat menambah pengalaman dan meningkatkan keterampilan kerja mempunyai dampak paling langsung terhadap kinerja. Senada dengan itu, Hasibuan (2006:77) menyatakan bahwa pelaksanaan program pelatihan membentuk dan meningkatkan kemampuan dan pengetahuan karyawan, sehingga diharapkan jika semakin sering program pelatihan dilaksanakan maka semakin tinggi pula tingkat kinerjanya. Menurut Mangkunegara (2012:52), tujuan umum pelatihan adalah (1) untuk mengembangkan keahlian, sehingga pekerjaan dapat diselesaikan dengan lebih cepat dan lebih efektif, (2) untuk mengembangkan pengetahuan, sehingga pekerjaan dapat diselesaikan secara rasional, dan (3) untuk mengembangkan sikap, sehingga menimbulkan kemauan kerjasama dengan teman-teman pegawai dan dengan manajemen (pimpinan). Beberapa pendapat tersebut menunjukkan bahwa pelatihan berpengaruh terhadap kinerja karyawan. Peningkatan kinerja karyawan merupakan prioritas perusahaan yang dapat dilakukan dengan mengembangkan kualitas tenaga kerja melalui pelatihan yang berkesinambungan. Hal ini disebabkan karena pelatihan menambah pengalaman dan meningkatkan keterampilan kerja sesuai dengan standar yang ditetapkan perusahaan.

\section{SIMPULAN DAN SARAN Simpulan}

Berdasarkan hasil analisis data dan pembahasan hasil penelitian maka dapat ditarik simpulan sebagai berikut. (1) Pelatihan berpengaruh positif dan signifikan terhadap kinerja karyawan pada LPD Kabupaten Buleleng, yang ditunjukkan dengan koefisien regresi yang positif 0,898 dengan nilai $t_{\text {hitung }}=10,947>t_{\text {tabel }}=2,009$ dan nilai probabilitas uji t 0,000 yang lebih kecil dari $\alpha=0,05$. Artinya, jika pelatihan semakin sering dilakukan, maka kinerja karyawan juga semakin tinggi. (2) Besar pengaruh pelatihan terhadap kinerja karyawan pada LPD Kabupaten Buleleng ditunjukkan dengan koefisien determinasi sebesar 0,706. Hal ini menunjukkan bahwa $70,6 \%$ variabel kinerja karyawan pada LPD Kabupaten Buleleng dipengaruhi oleh variabel pelatihan, sedangkan $29,4 \%$ dipengaruhi oleh faktor lain yang tidak termasuk dalam penelitian ini.

\section{Saran}

Berdasarkan simpulan diatas, maka dapat dikemukakan beberapa saran sebagai berikut. (1) Bagi pihak pengelola LPD di Kabupaten Buleleng, agar lebih memperhatikan program pelatihan terhadap karyawan sebagai upaya untuk meningkatkan kinerja karyawan, karena penelitian ini membuktikan bahwa pelatihan dapat mempengaruhi kinerja karyawan. Hal tersebut karena pelatihan dapat menambah pengalaman dan meningkatkan keterampilan kerja sesuai dengan standar yang ditetapkan perusahaan sehingga mendukung terciptanya kinerja yang tinggi (2) Bagi peneliti selanjutnya yang tertarik untuk mengkaji aspek yang serupa mengenai pengaruh pelatihan terhadap kinerja karyawan diharapkan untuk mengembangkan penelitian ini dengan menggunakan populasi dan sampel yang lebih luas, tidak hanya LPD di Kabupaten Buleleng, tetapi juga di kabupaten lainnya agar hasil penelitian lebih teruji keandalannya. (3) Berdasarkan hasil perhitungan koefisien determinasi sebesar 0,665 . Hal ini menunjukkan bahwa $66,5 \%$ kinerja karyawan dipengaruhi oleh pelatihan, sedangkan $33,5 \%$ dipengaruhi oleh faktor lain. Dengan demikian disarankan bagi peneliti selanjutnya dapat menggunakan variabel lain yang mempengaruhi kinerja karyawan seperti insentif finansial, insentif non finansial, motivasi kerja, kepuasan kerja, dan disiplin kerja.

\section{DAFTAR PUSTAKA}

Dantes, Nyoman. 2012 Metode Penelitian. Yogyakarta: Andi Offset.

Firdaus, M. 2007. Manajemen Agribisnis. Jakarta: Bumi Aksara.

Ghozali, \& Imam. 2011. Aplikasi Analisis Multivariate dengan Program SPSS. 
p-ISSN : 2599-1418

e-ISSN : 2599-1426

Semarang: Badan Penerbit Universitas Diponegoro.

Hasibuan \& Malayu S. P. 2006. Manajemen Dasar, Pengertian, dan Masalah. Jakarta: Bumi Aksara.

-------. 2012. Manajemen Sumber Daya Manusia. Jakarta: Bumi Aksara.

Ilyas, \& Yaslis. 2005. Kinerja Teori, Penilaian dan Penelitian. Jakarta: Pusat Kajian Ekonomi Kesehatan Kesehatan Fakultas Kesehatan Masyarakat, Universitas Indonesia.

Kusriyanto, Garda. 2003. Riset Sumber Daya Manusia. Jakarta: PT. Gramedia Pustaka Utama.

Mangkunegara, A. \& A. Anwar Prabu. 2003. Perencanaan dan Pengembangan Sumber. Daya Manusia. Bandung: Refika Aditama.

2005. Manajemen Sumber Daya Manusia Perusahaan. Bandung: PT. Remaja Rosdakarya.

------. 2012. Evaluasi Kinerja SDM. Bandung: Refika Aditama.

Mangkuprawira, S. \& Aida V. Hubeis. 2007. Manajemen Mutu Sumber Daya Manusia. Bogor: Ghalia Indonesia.

Nitisemito, \& Alex S. 2001. Manajemen Personalia. Bogor: Ghalia Indonesia.

Rivai, Veithzal. 2005. Manajemen Sumber Daya Manusia untuk Perusahaan, dari Teori ke Praktik. Jakarta: PT. Raja Grafindo Persada.

Simamora, Henry. 2006. Manajemen Sumber Daya Manusia. Yogyakarta: STIE YKPN.

Sugiyono. 2013. Metode Penelitian Bisnis. Bandung: CV. Alfabeta.

Sutrisno, Edy. 2010. Manajemen Sumber Daya Manusia. Jakarta: Kencana Prenada Media Group.

Wirawan. 2009. Evaluasi Kinerja Sumber Daya Manusia: Teori Aplikasi dan Penelitian. Jakarta: Salemba Empat.
Jurnal Pendidikan Ekonomi Undiksha

Volume 10 No. 2 Tahun 2018

Zuriah, Nurul. 2006. Metode Penelitian Sosial dan Pendidikan: Teori Aplikasi. Jakarta: Bumi Aksara. 